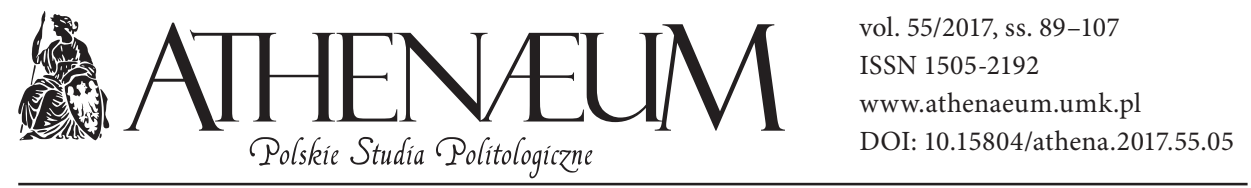

\title{
WPŁYW ORDYNACJI WYBORCZEJ I POLARYZACJI SCENY POLITYCZNEJ NA POZIOM FREKWENCJI WYBORCZEJ
}

\author{
THE IMPACT OF THE ELECTORAL SYSTEM AND THE \\ POLARIZATION OF THE POLITICAL SCENE \\ ON VOTER TURNOUT
}

Marcin Najbar*

\begin{abstract}
ABSTRAKT
Badanie determinant frekwencji wyborczej stanowi ważny obszar zainteresowań teorii wyboru publicznego. Celem artykułu jest ocena wpływu ordynacji wyborczej i polaryzacji sceny politycznej na frekwencję wyborczą. Przedstawione badanie empiryczne obejmuje wybory do parlamentów krajowych w 51 państwach w latach 1961-2014. W oparciu o dane pochodzące z projektu EMP zmierzona została polaryzacja sceny politycznej. Modele regresji dla wszystkich państw oraz dla Europy Zachodniej wykazały, że system wyborczy ma wpływ na poziom frekwencji wyborczej. W obu przypadkach systemy większościowe charakteryzują się niższą frekwencją niż systemy proporcjonalne. Mocny test zawierający efekty stałe dla krajów nie wykazał wpływu polaryzacji sceny politycznej na wielkość frekwencji. Brak związku przyczynowego pomiędzy polaryzacją a frekwencją może wynikać $\mathrm{z}$ ist-
\end{abstract}

Determinants of voter turnout are one of the most important areas of interest of public choice theory. This article aims to examine the impact of the electoral system and the polarization of the political scene on voter turnout. The survey covers elections to the national parliaments in 51 countries between 1961-2014. Data from the EMP project enabled the quantification of the polarization of the political scene. Regression models for all countries and for the Western Europe have shown that electoral system affects the level of the voter turnout. In both cases, the plurality/majority systems are characterized by a lower turnout than proportional systems. Powerful test with fixed effects for countries showed no impact of the polarization of the political scene on the level of the turnout. This may result from the presence of contradictory mechanisms binding polarity and the voter turnout.

* Akademia Leona Koźmińskiego w Warszawie. 
nienia wielu mechanizmów współzależności tych zmiennych, które zostały opisane w teoretycznej części artykułu.
Słowa kluczowe: teoria wyboru publicznego, frekwencja wyborcza, polaryzacja, ordynacja wyborcza

Keywords: public choice theory, voter turnout, polarization, electoral system

\section{WPROWADZENIE TEORETYCZNE}

Głosowanie jest najważniejszym źródłem legitymizacji władzy demokratycznej. Dla większości obywateli głosowanie jest jedynym kanałem partycypacji politycznej. Wysoka frekwencja zapewnia silną legitymację władzy politycznej (Downs, 1957; Mata Lopez, 2013). Dlatego też badanie determinant frekwencji wyborczej stanowi ważny obszar zainteresowań teorii wyboru publicznego.

Celem niniejszego badania jest weryfikacja hipotez dotyczących determinant poziomu frekwencji wyborczej w ujęciu międzynarodowym. W badaniu zostały postawione następujące hipotezy:

1) Na poziom frekwencji wpływ ma system wyborczy.

2) Na poziom frekwencji wpływ ma polaryzacja sceny politycznej.

Hipotezy te były dotychczas poddane weryfikacji w badaniach empirycznych, jednak nie dostarczyły jednoznacznych odpowiedzi (Gays, 2006a).

W części teoretycznej pokazana została skomplikowana współzależność trzech badanych zmiennych - polaryzacji sceny politycznej, ordynacji i frekwencji wyborczej. Przedstawione zostały najważniejsze kanały wpływu poszczególnych zmiennych na siebie pochodzące zarówno z teoretycznych jak i empirycznych źródeł literatury.

Oryginalność przeprowadzonego badania umożliwił dynamiczny rozwój bazy Manifesto Project Database (MPD), która została rozbudowana i uzupełniona w kolejnych projektach (m.in. Comparative Manifestos Project - CMP). W projektach kwantyfikacja programów politycznych partii w większości krajów demokratycznych po 1945 roku została przeprowadzona w oparciu o automatyczny proces kodowania komputerowego. Baza MPD pozwala na przeprowadzenie badań w obszarach o bogatym dorobku teoretycznym i weryfikację postawionych w literaturze przedmiotu hipotez. Przeprowadzone badanie charakteryzuje duża liczebność próby. Modele regresji zbudowane zostały dla 517 wyborów parlamentarnych w 51 krajach. 


\section{ZNACZENIE FREKWENCJI WYBORCZEJ}

W literaturze teoretycznej istnieje hipoteza określana jako efekt partyjny, mówiąca, że istnieją różnice w preferencjach wyborczych pomiędzy głosującymi a niegłosującymi. Efekt partyjny może występować, jeśli te same cechy socjoekonomiczne, które decydują o udziale w wyborach, wpływają także na preferencje dotyczące partii (Hansford, Gomez, 2015). Różnice pomiędzy dwoma ww. grupami obywateli oznaczają, że dobra jakość reprezentacji preferencji społecznych może zostać osiągnięta jedynie w przypadku wysokiej frekwencji. Niska frekwencja może mieć wpływ na wyniki wyborów i prowadzić do niedoreprezentowania niektórych grup społecznych (Mata Lopez, 2013). Badania empiryczne wykazały istnienie efektu partyjnego w Stanach Zjednoczonych oraz Niemczech. W obu przypadkach wyższa frekwencja prowadziła do lepszego wyniku partii lewicowych (Arnold, Freier 2015; Valasek, 2012).

Absencje wyborcze mogą wynikać m.in. z alienacji wyborców związanej $\mathrm{z}$ trudnościami ze znalezieniem odpowiedniej reprezentacji politycznej lub z obojętności wyborców oznaczającej brak dostrzegania różnic pomiędzy podobnymi do siebie programami partii (Fiorina, 1999). Alienacja może dotyczyć wyborców umiarkowanych ze względu na polaryzujące się elity polityczne oraz wyborców skrajnych w przypadku przesuwania się partii w stronę centrum (Hetheringon, 2008). Przykładem rosnącej obojętności wyborców, która ma negatywny wpływ na frekwencję wyborczą, są wybory do Parlamentu Europejskiego oraz wybory parlamentarne w krajach UE. Wskutek pogłębiającej się integracji europejskiej programy poszczególnych partii upodobniają się do siebie, co sprawia, że wyborcy nie dostrzegają różnic pomiędzy programami partii (Matakos, Troumpounis, Xefteris, 2015).

Niska frekwencja wyborcza nie ma jednoznacznie negatywnego charakteru. Absencje wyborcze są jedyną możliwością uwzględnienia siły preferencji wyborców, ponieważ w głosowaniu biorą udział jednostki, dla których znaczenie wyborów jest większe niż poniesione koszty (Valasek, 2012).

\section{FREKWENCJA WYBORCZA W TEORII WYBORU PUBLICZNEGO}

Teoria wyboru publicznego (TWP), zaliczana do nurtu nowej ekonomii instytucjonalnej, wykorzystuje koncepcję homo economicus do badania zjawisk niedotyczących gospodarowania, m.in. do badania jakości instytucji w sferze polityki. 
TWP zakłada racjonalność jednostek dążących do maksymalizacji własnej użyteczności. Wartościowanie odbywa się zgodnie z preferencjami odpowiadającymi wartościom i celom jednostek. Jednym z nurtów TWP jest ekonomiczna teoria demokracji, która traktuje głosowanie polityczne jako skuteczne narzędzie kontroli rynku politycznego, gdzie partie polityczne są nabywcami, a wyborcy oferentami głosów. Przedmiotem kontraktu są programy polityczne (Wilkin, 2005).

Istnieją dwa podejścia do frekwencji wyborczej. Pierwsze opiera się na socjodemograficznych cechach wyborców, drugie podejście to modelowanie w oparciu o racjonalny model jednostki porównującej korzyści z kosztami (Fumagalli, Narcisio, 2012; Mata Lopez, 2013).

W wąsko pojętym drugim podejściu pojedynczy głos wpływa na wynik wyborów tylko wówczas, gdy kandydaci (partie) otrzymali identyczną liczbę głosów lub jeśli przeciwnik ma jeden głos przewagi. Można zatem zauważyć, że w przypadku dużych populacji wyborców prawdopodobieństwo (P), że jeden głos zaważy na wynikach wyborów, jest bardzo niskie. Korzyścią głosowania dla wyborcy (B) jest różnica pomiędzy oczekiwanymi użytecznościami działań dwóch kandydatów (partii) a oczekiwanymi korzyściami wyboru to $\left(\mathrm{B}^{\star} \mathrm{P}\right)$. Ponieważ $(\mathrm{P})$ jest bliskie zera, oczekiwane korzyści z dokonanego wyboru są znacznie mniejsze niż koszty (C), które musi ponieść wyborca, aby oddać głos $\left(\mathrm{P}{ }^{\star} \mathrm{B}-\mathrm{C}<0\right)$. Oznacza to, że racjonalny wyborca nie powinien brać udziału w wyborach. W rzeczywistości jednak udział w wyborach jest zjawiskiem masowym, co określane jest jako paradoks głosowania (Mata Lopez, 2013; Mueller, 2003).

W literaturze teoretycznej paradoks głosowania rozwiązany został m.in. poprzez zmianę sposobu kalkulacji użyteczności wyborcy. Ponieważ głosowanie zaspokaja potrzeby obywatelskie związane $\mathrm{z}$ patriotyzmem i postawą obywatelską, najprostszą metodą pogodzenia racjonalności z aktem głosowania jest nadanie pewnej wartości samemu aktowi głosowania (D) niezależnie od jego wpływu na wynik (Riker, Ordeshook, 1968). Akt głosowania nie jest zatem traktowany jako inwestycja, lecz jako konsumpcja (Mata Lopez, 2013). Takie podejście oznacza, że korzyści z głosowania są różnicą pomiędzy zyskiem psychicznym i kosztami wzięcia udziału w wyborach $(\mathrm{D}-\mathrm{C})$. Inną próbą rozwiązania paradoksu głosowania jest hipoteza ekspresywnego wyborcy, która mówi, że wyborca głosuje nie po to, by przesądzić o wyniku wyborów, ale aby wyrazić swoją opinię zgodną z dobrem publicznym. Użyteczność wypływająca $\mathrm{z}$ aktu głosowania zawarta jest w zmiennej (D), która przedstawione jest jako funkcja (B), np. (D = D’ + B), gdzie D’ obejmuje aspekty, tj. obowiązek oby- 
watelski. Zmiana sposobu kalkulacji użyteczność pozwala wyjaśnić przyczyny wysokiej frekwencji wyborczej. Hipoteza ekspresywnego wyborcy może być przeciwstawiona zatem głosowaniu strategicznemu oznaczającemu głosowanie ze względu na możliwość wpływu na wynik (Mueller, 2003). Paradoks głosowania może być rozwiązany również w oparciu o hipotezę etycznego wyborcy, która uwzględnia preferencje społeczne jednostek. Przyjęte jest założenie, że wyborca ma dwa zestawy preferencji - samolubny oraz etyczny, uwzględniający dobrostan całego społeczeństwa (Myatt, 2012). Podczas głosowania preferencje etyczne są silniejsze niż samolubne. Hipoteza ta ma zasadniczą wadę, ponieważ dostarcza racjonalizacji aktu głosowania ex post natomiast nie pozwala na stworzenie teorii, która mogłaby mieć wartość predykcyjną. W literaturze szeroko opisane są także behawioralne aspekty wyborów związanych z bodźcami wzmacniającymi z dzieciństwa. Zachowania wyborcze wyjaśniane są w kontekście uwarunkowań społecznych. Istnieje również hipoteza, że głosowanie jest nawykiem (Mueller, 2003).

\section{WPŁYW POLARYZACJI SCENY POLITYCZNEJ NA FREKWENCJĘ WYBORCZA}

Modelowanie przestrzenne programów partii politycznych odbywa się na zaproponowanej przez Downsa (1957) jednowymiarowej osi lewica-prawica (L-P). Jest to najpowszechniej wykorzystywane narzędzie kwantyfikacji programów partii politycznych oraz preferencji i decyzji wyborców. Oś L-P umożliwia zarówno porównania pomiędzy krajami, jak i mierzenie polaryzacji sceny politycznej. Ze względu na różne definicje lewicy i prawicy w poszczególnych krajach porównania międzynarodowe obarczone są ryzykiem (Dalton, 2008).

Pomiędzy polaryzacją a frekwencją zachodzi przyczynowe sprzężenie zwrotne. Frekwencja jest zależna od położenia partii na osi L-P, ponieważ wyborcy biorą udział $\mathrm{w}$ wyborach wtedy, gdy istnieje partia nieodbiegająca znacznie od ich preferencji. Z drugiej strony popularna jest hipoteza, że niska frekwencja zwiększa polaryzację sceny politycznej (Steenkiste, 2015). W rezultacie problemem tworzonych modeli jest endogeniczność zmiennych (Hansford, Gomez, 2010). W przypadku badania wpływu frekwencji wyborczej na polaryzację sceny politycznej częstym zabiegiem jest wprowadzenie zmiennych instrumentalnych, egzogenicznych wobec zmiennej objaśnianej. Frekwencja wyborcza często zastępowana jest przez zmienną określającą pogodę w dniu 
wyborów (Hansford, Gomez, 2010). Inną możliwością jest badanie działań mających na celu zwiększenie frekwencji tj. zmniejszenie kosztów głosowania, dotowanie głosowania, głosowanie pocztą. Zmiany frekwencji spowodowane są $\mathrm{w}$ tym przypadku przez czynniki niezwiązane $\mathrm{z}$ usytuowaniem partii na scenie politycznej (Valasek, 2012).

Wiele początkowych badań i teorii dużą wagę przypisywało liczbie partii które biorą udział w wyborach. Bardziej istotna jest jednak rywalizacja pomiędzy partiami oraz polaryzacja sceny politycznej (Murphy 2009). Według Downsa (1957) partie polityczne powinny dostosowywać się do rozkładu elektoratu na osi L-P.W przypadku rozkładu jednomodalnego partie powinny przesuwać się w stronę centrum, w przypadku rozkładu dwumodalnego system powinien ulec polaryzacji, a w przypadku rozkładu wielomodalnego najbardziej prawdopodobny jest system wielopartyjny, w którym partie umiejscawiają się jak najbliżej mody. W systemie wielopartyjnym partie powinny być przywiązane do swoich ideologii, a w systemie dwupartyjnym powinny przesuwać się w stronę centrum sceny politycznej zgodnie $\mathrm{z}$ teorią medianowego wyborcy (Black, 1948).

Badania empiryczne nie potwierdzają teorii medianowego wyborcy. W wielu krajach, m.in. w Stanach Zjednoczonych, postępuje polaryzacja sceny politycznej pomimo niewielkiej polaryzacji społeczeństwa (Fiorina, 1999). Celem polaryzacji elit jest chęć utrzymania żelaznego elektoratu. Postulowane przesunięcie partii w stronę centrum prowadziłoby do alienacji części wyborców i ich rezygnacji z udziału w wyborach (Hansford, Gomez, 2010).

Zarówno polaryzacja elit, jak i społeczeństwa może wynikać z rosnącej ideologizacji. Ideologie pozwalają obywatelom na określenie swojego stanowiska w przypadku ograniczonych zasobów informacyjnych. Ideologizacja społeczeństwa może mieć podłoże psychobehawioralne. Większość ludzi otacza się osobami o podobnych poglądach, przez co ignorują część informacji, a jednocześnie przeceniają jakość informacji, które są im dostarczane. W odpowiedzi na ideologizację społeczeństwa partie polityczne deklarują poparcie dla wybranej ideologii. Aby takie działania przyniosły korzyści, ideologie powinny być spójne, stabilne w czasie i poparte odpowiednimi działaniami (Downs, 1957). Polaryzacja wynikająca z ideologizacji społeczeństwa może prowadzić do wyższej frekwencji wyborczej (Ortoleva, Snowberg, 2013).

Polaryzacja może mieć podobny wpływ na frekwencję jak związane z nią kampanie negatywne. Pomimo że większość wyborców krytycznie odnosi się do kampanii negatywnych, wywierają one silny wpływ na społeczeństwo i zawierają duży ładunek informacyjny, wobec czego umiarkowani wyborcy biorą udział 
w wyborach w przypadku polaryzacji sceny politycznej (Hetherington, 2008). Niektóre badania wskazują jednak, że polaryzacja obniża frekwencję wyborczą, w szczególności wśród obywateli z niższym poziomem wykształcenia i wiedzy politycznej (Rogowski, 2015).

\section{WPŁYW ORDYNACJI WYBORCZEJ NA FREKWENCJĘ WYBORCZA}

Ordynacja wyborcza oznacza sposób, w jaki głosy w wyborach przeliczane są na miejsca w parlamencie. Badania empiryczne dotyczące wpływu systemów wyborczych na frekwencję koncentrują się na porównaniu systemów proporcjonalnych z większościowymi (Barone, De Blasio, 2013).W literaturze przedmiotu wielokrotnie weryfikowana była hipoteza, że większa proporcjonalność systemu wyborczego prowadzi do wyższej frekwencji (Gays, 2006b).

Powyższa hipoteza opiera się na trzech argumentacjach. Po pierwsze, im bardziej proporcjonalna jest zasada wyborcza, tym większe prawdopodobieństwo, że pojedynczy głos ma znaczenie. W przypadku jednomandatowych okręgów wyborczych wpływ pojedynczego głosu na wynik wyborów charakteryzuje się wysoką zmiennością pomiędzy okręgami, ale najczęściej jest niewielki. Po drugie, systemy proporcjonalne charakteryzują się większą liczbą partii. W rezultacie większa liczba wyborców może znaleźć partię reprezentujące ich preferencje, co zmniejsza alienację wyborców. Po trzecie, większościowe zasady wyborcze prowadzą do przesuwania się partii w stronę centrum. Powoduje to wzrost obojętności wyborców (indifference) niedostrzegających różnic pomiędzy partiami. Z kolei zasady proporcjonalne prowadzą do różnicowania się programów politycznych i ich polaryzacji, co powoduje wzrost frekwencji związany z rosnącymi korzyściami wyborcy związanymi z wyborem danej partii. Zasada wyborcza ma zatem wpływ na umiejscowienie programów politycznych na osi L-P (Matakos i in., 2015).

Możliwa jest jednak następująca kontrargumentacja. Systemy większościowe są prostsze do zrozumienia dla wyborcy, prowadzą do przewidywalnych wyników i rzadziej oznaczają konieczność formowania się koalicji, co może mieć pozytywne przełożenie na frekwencję wyborczą (Ladner, Milner, 1999).

Związek pomiędzy proporcjonalnością systemu i frekwencją może być pozorny. Zarówno ordynacja wyborcza, jak i poziom frekwencji mogą być zależne od czynników instytucjonalno-kulturowych (Ladner, Milner, 1999). 


\section{MODEL}

\section{Dane}

W badaniu uwzględnione zostały wybory do parlamentów krajowych w latach 1961-2014 w 51 państwach ${ }^{1}$. Poszczególne wybory traktowane są jako pojedyncze obserwacje. Analizy porównawcze pomiędzy krajami (cross-country) są rekomendowane dla tego typu badań (Ladner, Milner, 1999; Sanz, 2015).

Zmienne makroekonomiczne, tj. wzrost PKB, poziom bezrobocia i liczba ludności krajów, wykorzystane w modelu, pochodzą z bazy Banku Światowego (http://data.worldbank.org/). Zmienne dotyczące obowiązku głosowania, systemu wyborczego oraz frekwencji w wyborach pochodzą z bazy IDEA (http:// www.idea.int/).

Zmierzenie polaryzacji sceny politycznej umożliwiają dane pochodzące z Manifesto Project Database (https://manifestoproject.wzb.eu/; zob. tabela 2). W projekcie Comparative Manifestos Project (CMP) partie polityczne zostały umiejscowione na osi lewica-prawica w oparciu o publikowane przed wyborami parlamentarnymi programy, w procesie automatycznego kodowania komputerowego (Volkens i in., 2015). Kwantyfikacja programów partii politycznych dokonana została dla większości krajów demokratycznych po 1945 roku. W niniejszym badaniu do zmierzenia polaryzacji wykorzystany został indeks Daltona, który ze względu na unormowanie danych pochodzących z CMP ma postać odchylenia standardowego położenia partii politycznych na osi L-P w poszczególnych wyborach (Matakos i in., 2015).

Tabela 1. Opisy zmiennej objaśnianej i zmiennych objaśniających

\begin{tabular}{|l|l|}
\hline \multicolumn{1}{|c|}{ Zmienna } & \multicolumn{1}{c|}{ Opis zmiennej } \\
\hline Frekwencja & $\begin{array}{l}\text { Liczba oddanych głosów (wliczając nieważne) podzielona przez liczbę zarejestro- } \\
\text { wanych wyborców }\end{array}$ \\
\hline Wzrost_PKB-1 & Wzrost PKB kraju w roku poprzedzającym wybory \\
\hline Bezrobocie-1 & Bezrobocie (\%) w kraju w roku poprzedzającym wybory \\
\hline Populacja & Liczba mieszkańców kraju w mln \\
\hline Obowiazkowe & $\begin{array}{l}\text { Zmienna binarna przyjmująca wartość } 1 \text {, jeśli głosowanie jest obowiązkowe, i } 0 \\
\text { w przeciwnym przypadku }\end{array}$ \\
\hline
\end{tabular}

1 Większość krajów europejskich, Stany Zjednoczone, Kanada, Meksyk, RPA, Japonia, Korea Płd., Izrael, Australia i Nowa Zelandia. 


\begin{tabular}{|c|l|}
\hline \multicolumn{1}{|c|}{ Zmienna } & \multicolumn{1}{c|}{ Opis zmiennej } \\
\hline S1 & Zmienna binarna - alternatywny system większościowy (Australia) \\
\hline S2 & $\begin{array}{l}\text { Zmienna binarna - system większościowy pierwszy na mecie (first past the } \\
\text { post) }\end{array}$ \\
\hline S3 & Zmienna binarna - system większościowy dwurundowy (Francja) \\
\hline S4 & $\begin{array}{l}\text { Zmienna binarna - system mieszany, gdzie alokacja miejsc w systemie propor- } \\
\text { cjonalnym zależna jest od wyników głosowania większościowego }\end{array}$ \\
\hline S5 & $\begin{array}{l}\text { Zmienna binarna - system mieszany, gdzie alokacja miejsc w systemie propor- } \\
\text { cjonalnym nie jest zależna od wyników głosowania większościowego }\end{array}$ \\
\hline S6 & $\begin{array}{l}\text { Zmienna binarna - system proporcjonalny pojedynczy głos przechodni (single } \\
\text { transferable vote) }\end{array}$ \\
\hline- & $\begin{array}{l}\text { Pominięta zmienna binarna - system proporcjonalny list partyjnych (list } \\
\text { proportional represenation) }\end{array}$ \\
\hline Bóżnica wyników pierwszej (zwycięskiej) i drugiej partii \\
\hline Polaryzacja & $\begin{array}{l}\text { Odchylenie standardowe zmiennej oznaczającej położenie partii na osi L-P } \\
\text { zważone wynikiem wyborów }\end{array}$ \\
\hline
\end{tabular}

Tabela 2. Charakterystyki zmiennych egzogenicznych modelu

\begin{tabular}{|c|c|c|c|c|}
\hline $\begin{array}{c}\text { Zmienne } \\
\text { objaśniające }\end{array}$ & Rodzaj zmiennej & $\begin{array}{c}\text { Charakter } \\
\text { zmiennej }\end{array}$ & $\begin{array}{c}\text { Źródło } \\
\text { danych }\end{array}$ & $\begin{array}{c}\text { Znaczenie } \\
\text { zmiennej }\end{array}$ \\
\hline Polaryzacja & polityczna & zmienna ciągła & MPD & weryfikacja hipotez \\
\hline Bliskosc_wynikow & polityczna & zmienna ciągła & MPD & kontrolna \\
\hline Populacja & socjoekonomiczna & zmienna ciągła & World Bank & kontrolna \\
\hline Wzrost_PKB-1 & socjoekonomiczna & zmienna ciągła & World Bank & kontrolna \\
\hline Bezrobocie-1 & socjoekonomiczna & zmienna ciągła & World Bank & kontrolna \\
\hline Obowiazkowe & instytucjonalna & zmienna binarna & IDEA & kontrolna \\
\hline Zmienne S1-S6 & instytucjonalne & zmienne binarne & IDEA & weryfikacja hipotez \\
\hline
\end{tabular}

W stworzonym modelu zmienną objaśnianą jest frekwencja wyborcza. Do wyjaśniania zmienności frekwencji wyborczej w badaniach empirycznych wykorzystywane są zmienne kulturowe, socjoekonomiczne, polityczne, demograficzne oraz instytucjonalne (Geys, 2006a). W związku z postawionymi w badaniu hipotezami do zmiennych objaśniających należą polaryzacja sceny politycznej oraz grupa zmiennych binarnych (zerojedynkowych) kodujących ordynację wyborczą. Zmienne S1, S2 i S3 oznaczają ordynacje większościowe, zmienne S4 i S5 oznaczają ordynacje mieszane, a zmienne S6 oraz pominięta zmienna oznaczają systemy proporcjonalne (zob. tabela 1). Jako kontrolujące zmienne 


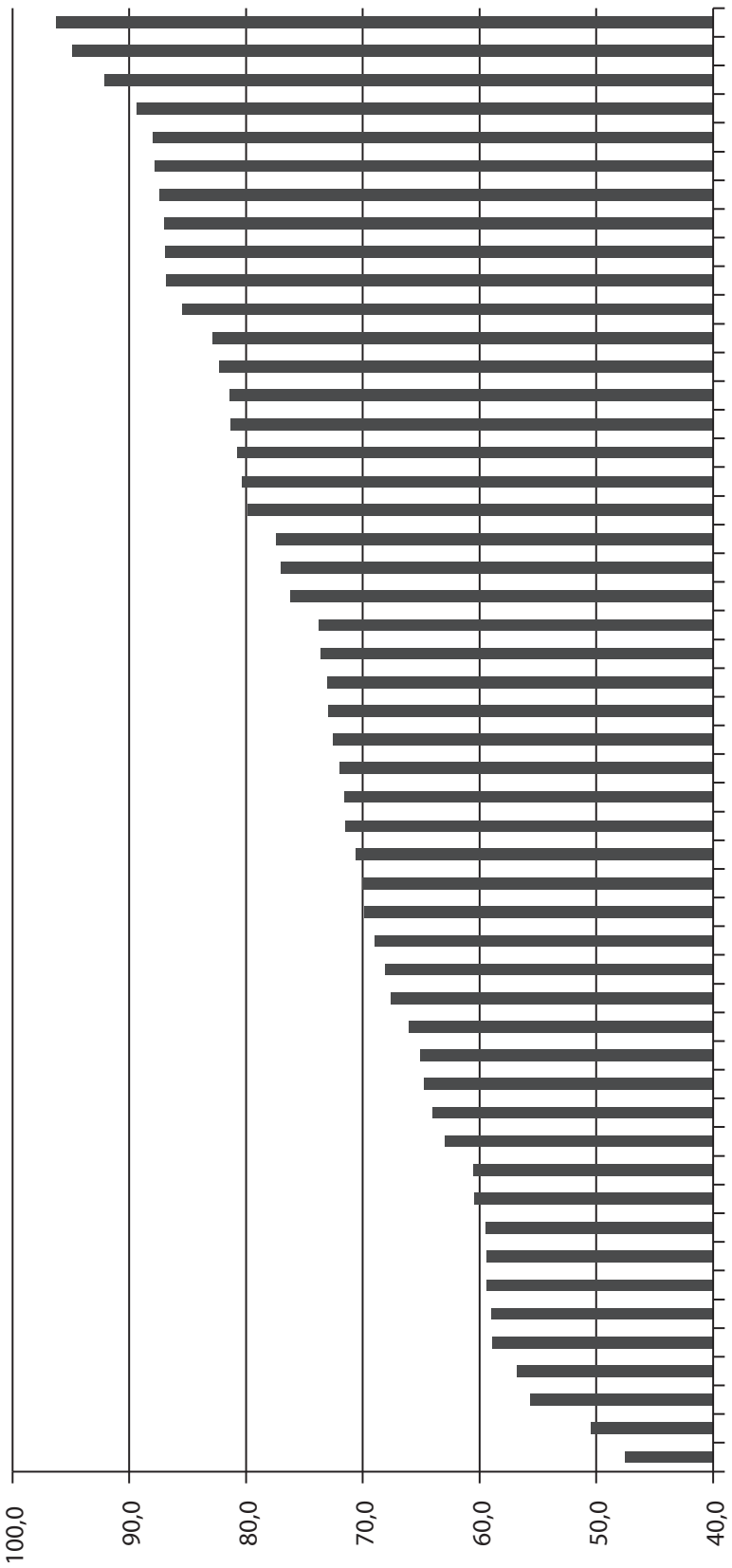

expew

e!|exisn

е!̣ळ|əg

6.nquəsyn7

e!pue|s|

อ!̣zsn

$\lambda d / 3$

КцวоғМ

е! כәMZS

ẹueo

е!puejəZ EMON

KJuə!N

е!рue아

e!ueqIV

e?

$\forall d y$

e!ढวMıON

|әеגz|

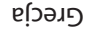

uez̦p!əquəz

емі07

е!pueju!-

e!uedzs!H

әuozวoup

е!’еMOłs

e! ןe6nulod

КцЈәZว

е!uezКАg ех|ә!м

е!рuе|시

ереиеу

е!วued

!uM아s

eu!̣exyn

e!uoder

е!мерłоW

ептемлочว

রибз

е!ıeбłng

e!znd פ

е!uols马

е!иopəəew

ए!qдәS

e!̣ununy

elsoy

y KsyәW

еи!мобәздән ! ẹușog

емоupnłod еәлоу

е!цәшин

EM!!

e!ıeग!emzs

eyslod 
objaśniające do modelu dołączone zostały zmienne socjoekonomiczne tj. wielkość populacji kraju, wzrost PKB i inflacja w roku poprzedzającym wybory, zmienna polityczna określająca różnicę wyników dwóch zwycięskich partii oraz binarna zmienna instytucjonalna określająca obowiązek głosowania (zob. tabela 1 i tabela 2; Dassonneville, Hooghe, 2015; Geys, 2006b).

Frekwencja wyborcza charakteryzuje się dużą zmiennością pomiędzy badanymi krajami (zob. rysunek 1). W przypadku Polski średnia frekwencja wynosi $48 \%$, a w przypadku krajów takich jak: Malta, Australia i Belgia - ponad 90\%. Różnice pomiędzy krajami wynikają w znacznej mierze z czynników kulturowych, trudnych do uchwycenia przez zmienne objaśniające postulowane w literaturze przedmiotowej. Zmienność ta może zostać uwzględniona w modelu poprzez dodanie zmiennych binarnych dla poszczególnych krajów.

\section{Specyfikacja modelu}

Dane dotyczące wyborów mają charakter mocno niezbilansowanego panelu (unbalanced panel). Wybory odbywają się w różnych odstępach czasu dla różnych krajów, z reguły co kilka lat. W wielu przypadkach odstępy pomiędzy kolejnymi wyborami w danym kraju są różne. Wobec tego autor artykułu postanowił potraktować dane jako przekrojowe (cross-section) i zastosować model regresji oszacowany metodą najmniejszych kwadratów $(O L S)$. Wyborowi liniowego modelu regresji sprzyja rozkład empiryczny zmiennej objaśnianej frekwencji, która ma przybliżony rozkład normalny (zob. rysunek 2).

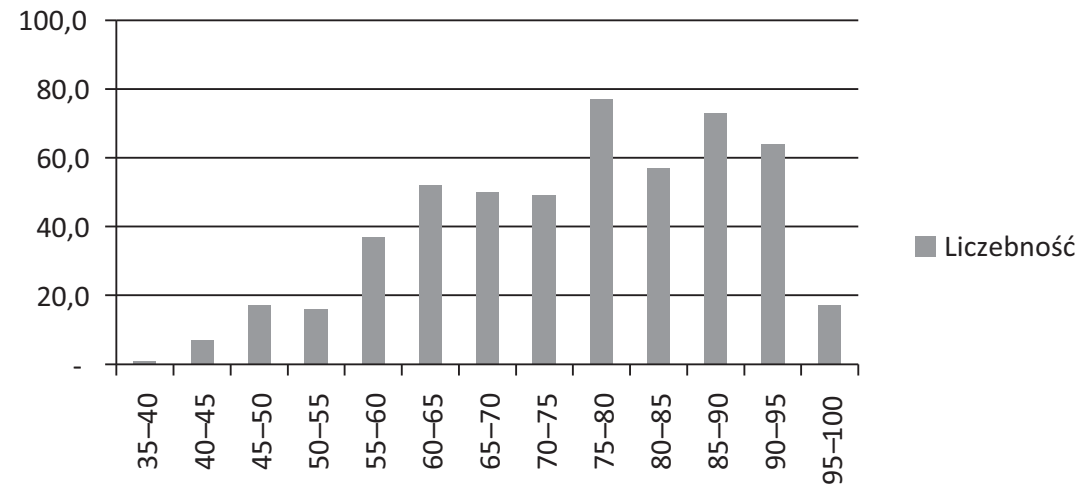

Rysunek 2. Liczebność przedziałów zmiennej objaśnianej frekwencji 
Oszacowane zostały modele regresji liniowej dla wszystkich krajów, wykorzystujące 517 obserwacji (modele (1), (2), (7); zob. tabela 3 i tabela 4). Dodatkowo autor postanowił oszacować modele dla Europy Wschodniej² oparte na 129 obserwacjach (modele (3), (4), (8); zob. tabela 3 i tabela 4) oraz dla Europy Zachodniej ${ }^{3}$ oparte na 246 obserwacjach (modele (5), (6), (9); zob. tabela 3 i tabela 4). Modele dla Europy Wschodniej i Europy Zachodniej obejmują kraje zbliżone geograficznie oraz kulturowo.

W modelach (1), (3), (5) weryfikowana jest hipoteza dotycząca wpływu systemu wyborczego na frekwencję wyborczą, a w modelach (2), (4), (6) weryfikowane są jednocześnie obie postawione hipotezy, tzn. wpływ systemu wyborczego i polaryzacji sceny politycznej na frekwencję wyborczą (zob. tabela 3). W modelach tych nie ma możliwości dołączenia zmiennych binarnych dla poszczególnych krajów, ponieważ zmienne te skorelowane są liniowo ze zmiennymi binarnymi dla ordynacji wyborczej.

W modelach (7), (8), (9) weryfikowana jest hipoteza dotycząca wpływu polaryzacji sceny politycznej na frekwencję wyborczą (zob. tabela 4). W modelach dołączone zostały zmienne binarne dla krajów, co pozwala na kontrolę czynników instytucjonalno-kulturowych i wzmacnia moc przeprowadzonego testu.

Tabela 3. Oszacowania modeli (1) - (6)

\begin{tabular}{|c|c|c|c|c|c|c|}
\hline \multirow{2}{*}{$\begin{array}{c}\text { Zmienna } \\
\text { objaśniająca }\end{array}$} & \multicolumn{2}{|c|}{ Wszystkie kraje } & \multicolumn{2}{c|}{ Europa Wschodnia } & \multicolumn{2}{c|}{ Europa Zachodnia } \\
\cline { 2 - 7 } & $\mathbf{( 1 )}$ & $\mathbf{( 2 )}$ & $\mathbf{( 3 )}$ & $\mathbf{( 4 )}$ & $\mathbf{( 5 )}$ & $\mathbf{( 6 )}$ \\
\hline \multirow{3}{*}{ Wyraz stały } & 647,3 & 627,0 & 814,8 & 815,6 & 469,0 & 457,1 \\
\cline { 2 - 7 } & {$[83,21]^{* * *}$} & {$[84,84]^{* * *}$} & {$[273,2]^{* * *}$} & {$[280,0]^{* * *}$} & {$[112,6]^{* * *}$} & {$[114,1]^{* * *}$} \\
\hline \multirow{2}{*}{ Polaryzacja } & & 0,273 & & $-0,030$ & & 0,161 \\
\cline { 2 - 7 } & & {$[0,09966]^{* * *}$} & & {$[0,2414]$} & & {$[0,1124]$} \\
\hline \multirow{2}{*}{$\begin{array}{c}\text { Bliskosc_ } \\
\text { wynikow }\end{array}$} & $-0,053$ & $-0,049$ & 0,097 & 0,097 & 0,217 & 0,205 \\
\hline \multirow{2}{*}{\begin{tabular}{c} 
Populacja \\
\cline { 2 - 7 }
\end{tabular}} & {$[0,05276]$} & {$[0,05122]$} & {$[0,1028]$} & {$[0,1032]$} & {$[0,09754]^{* *}$} & {$[0,09612]^{* *}$} \\
\cline { 2 - 7 } & $-0,023$ & $-0,025$ & $-0,029$ & $-0,031$ & $-0,015$ & $-0,012$ \\
\hline
\end{tabular}

2 Estonia, Litwa, Łotwa, Czechy, Węgry, Polska, Słowacja, Albania, Bośnia i Hercegowina, Bułgaria, Chorwacja, Grecja, Macedonia, Mołdawia, Rumunia, Serbia, Słowenia, Turcja, Ukraina.

3 Cypr, Malta, Austria, Belgia, Dania, Finlandia, Francja, Niemcy, Islandia, Włochy, Luksemburg, Holandia, Norwegia, Portugalia, Hiszpania, Szwecja, Wielka Brytania, Irlandia, Szwajcaria. 


\begin{tabular}{|c|c|c|c|c|c|c|}
\hline \multirow{2}{*}{$\begin{array}{c}\text { Zmienna } \\
\text { objaśniająca }\end{array}$} & \multicolumn{2}{|c|}{ Wszystkie kraje } & \multicolumn{2}{|c|}{ Europa Wschodnia } & \multicolumn{2}{|c|}{ Europa Zachodnia } \\
\hline & (1) & (2) & (3) & (4) & (5) & (6) \\
\hline \multirow{2}{*}{ Wzrost_PKB-1 } & $-30,8$ & $-31,8$ & $-44,0$ & $-44,0$ & 39,9 & 35,5 \\
\hline & {$[9,928]^{\star * *}$} & {$[10,22]^{* * *}$} & {$[16,81]^{\star *}$} & {$[16,88]^{* *}$} & {$[25,18]$} & {$[24,92]$} \\
\hline \multirow{2}{*}{ Bezrobocie-1 } & $-34,2$ & $-31,1$ & $-28,0$ & $-28,0$ & 0,7 & 1,0 \\
\hline & {$[9,455]^{\star * *}$} & {$[9,528]^{* * *}$} & {$[13,40]^{\star *}$} & {$[13,42]^{\star *}$} & {$[16,26]$} & {$[16,07]$} \\
\hline \multirow{2}{*}{ Rok } & $-0,285$ & $-0,276$ & $-0,372$ & $-0,373$ & $-0,198$ & $-0,192$ \\
\hline & {$[0,04194]^{\star * *}$} & {$[0,04263]^{* * *}$} & {$[0,1365]^{* * *}$} & {$[0,1396]^{* * *}$} & {$[0,05661]^{* * *}$} & {$[0,05724]^{* * *}$} \\
\hline \multirow{2}{*}{ Obowiazkowe } & 4,232 & 4,595 & 8,874 & 8,972 & 11,900 & 12,136 \\
\hline & {$[1,453]^{* * *}$} & {$[1,456]^{\star * *}$} & {$[3,426]^{\star *}$} & {$[3,670]^{\star *}$} & {$[1,249]^{* * *}$} & {$[1,306]^{* * *}$} \\
\hline \multirow{2}{*}{ S1 } & 11,666 & 10,974 & & & & \\
\hline & {$[1,694]^{\star * *}$} & {$[1,647]^{* * *}$} & & & & \\
\hline \multirow{2}{*}{ S2 } & $-4,561$ & $-4,262$ & & & $-6,536$ & $-6,772$ \\
\hline & {$[1,401]^{* * *}$} & {$[1,43]^{* * *}$} & & & {$[2,281]^{* * *}$} & {$[2,229]^{* * *}$} \\
\hline \multirow{2}{*}{ S3 } & $-7,515$ & $-7,423$ & & & $-8,668$ & $-8,680$ \\
\hline & {$[1,709]^{\star * *}$} & {$[1,733]^{\star * *}$} & & & {$[2,456]^{* * *}$} & {$[2,403]^{* * *}$} \\
\hline \multirow{2}{*}{ S4 } & $-5,194$ & $-4,774$ & $-5,123$ & $-5,117$ & 6,000 & 6,179 \\
\hline & {$[1,888]^{\star * *}$} & {$[1,863]^{\star *}$} & {$[3,296]$} & {$[3,313]$} & {$[2,727]^{\star *}$} & {$[2,653]^{\star *}$} \\
\hline \multirow{2}{*}{ S5 } & $-9,117$ & $-9,130$ & $-3,807$ & $-3,803$ & & \\
\hline & {$[1,341]^{\star * *}$} & {$[1,342]^{* * *}$} & {$[3,374]$} & {$[3,418]$} & & \\
\hline \multirow{2}{*}{ S6 } & $-3,588$ & $-3,409$ & & & $-5,746$ & $-5,443$ \\
\hline & {$[2,936]$} & {$[2,934]$} & & & {$[2,834]^{\star *}$} & {$[2,857]^{*}$} \\
\hline L. obserwacji & 517 & 517 & 129 & 129 & 246 & 246 \\
\hline L. parametrów & 13 & 14 & 9 & 10 & 11 & 12 \\
\hline $\mathrm{R} 2$ & $40,0 \%$ & $40,8 \%$ & $42,5 \%$ & $42,6 \%$ & $35,8 \%$ & $36,3 \%$ \\
\hline Adj. R2 & $38,5 \%$ & $39,3 \%$ & $36,6 \%$ & $36,1 \%$ & $32,5 \%$ & $32,7 \%$ \\
\hline test F & $27,97^{\star * *}$ & $26,69^{\star * *}$ & $7,157^{\star * *}$ & $6,552^{\star * *}$ & $10,84^{\star * *}$ & $10,16^{\star * *}$ \\
\hline $\begin{array}{c}\text { Norm test Chi } \\
\wedge 2 \\
\end{array}$ & $61,184^{* * *}$ & $53,78^{* * *}$ & 1,163 & 1,147 & $48,948^{* * *}$ & $46,973^{* * *}$ \\
\hline Hetero test $(\mathrm{F})$ & $3,8008^{* * *}$ & $3,5144^{* * *}$ & $3,395^{* * *}$ & $3,4191^{\star * *}$ & $3,5251^{\star * *}$ & $3,2541^{\star * *}$ \\
\hline Hetero-X (F) & $3,1173^{* * *}$ & $2,7104^{\star \star \star}$ & $2,7683^{\star \star *}$ & 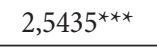 & $3,1130^{* * *}$ & $2,7018^{\star \star \star}$ \\
\hline RESET23 (F) & $4,1804^{* *}$ & $3,8303^{* *}$ & $3,3617^{* * *}$ & $7,5546^{\star * *}$ & 1,817 & 2,494 \\
\hline
\end{tabular}

Oszacowania parametrów modeli regresji liniowej metodą najmniejszych kwadratów (OLS); Błędy standardowe HCSE; Zmienna objaśniana: frekwencja; Błędy oszacowania znajdują się w nawiasach kwadratowych.

${ }^{\star} \mathrm{p}<0,05 ;{ }^{\star *} \mathrm{p}<0,01 ;{ }^{\star * *} \mathrm{p}<0,001$. 
Tabela 4. Oszacowania modeli (7) - (9)

\begin{tabular}{|c|c|c|c|c|c|c|}
\hline \multirow{2}{*}{\begin{tabular}{|c|c}
$\begin{array}{c}\text { Zmienna } \\
\text { objaśniająca }\end{array}$ \\
Wyraz stały \\
\end{tabular}} & \multicolumn{2}{|c|}{ Wszystkie kraje (7) } & \multicolumn{2}{|c|}{ Europa Wschodnia (8) } & \multicolumn{2}{|c|}{ Europa Zachodnia (9) } \\
\hline & 594,88 & {$[56,75]^{* * *}$} & 795,76 & {$[279,9]^{* * *}$} & 585,18 & {$[61,12]^{\star * *}$} \\
\hline Polaryzacja & 0,04 & {$[0,06595]$} & 0,07 & {$[0,2507]$} & 0,08 & {$[0,06927]$} \\
\hline Bliskosc_wynikow & 0,00 & {$[0,0305]$} & 0,03 & {$[0,1064]$} & $-0,15$ & {$[0,05603]^{* * *}$} \\
\hline Wzrost_PKB-1 & $-28,09$ & {$[8,868]^{* * *}$} & $-35,30$ & {$[14,87]^{\star *}$} & $-25,70$ & {$[12,41]^{\star *}$} \\
\hline Bezrobocie-1 & $-7,74$ & {$[11,51]$} & $-17,69$ & {$[28,02]$} & $-8,90$ & {$[9,265]$} \\
\hline Rok & $-0,26$ & {$[0,02838]^{* * *}$} & $-0,36$ & {$[0,1407]^{* *}$} & $-0,25$ & {$[0,03044]^{* * *}$} \\
\hline Obowiazkowe & 4,58 & {$[1,472]^{\star * *}$} & $-2,31$ & {$[8,162]$} & 5,29 & {$[1,44]^{* * *}$} \\
\hline Albania & 5,33 & {$[10,19]$} & & & & \\
\hline Armenia & $-13,48$ & {$[8,119]^{*}$} & & & & \\
\hline Australia & 12,16 & {$[7,318]^{*}$} & & & & \\
\hline Austria & 9,69 & {$[7,179]$} & & & 2,68 & {$[2,34]$} \\
\hline Belgia & 9,28 & {$[7,329]$} & & & 1,55 & {$[1,983]$} \\
\hline $\begin{array}{l}\text { Bośnia } \\
\text { i Hercegowina }\end{array}$ & $-9,75$ & {$[10,42]$} & $-11,19$ & {$[12,18]$} & & \\
\hline Bułgaria & $-8,86$ & {$[7,93]$} & $-12,83$ & {$[8,28]$} & & \\
\hline Kanada & $-7,18$ & {$[7,163]$} & & & & \\
\hline Chorwacja & $-7,60$ & {$[7,859]$} & $-11,18$ & {$[8,324]$} & & \\
\hline Cypr & 10,03 & {$[7,874]$} & & & 1,69 & {$[3,418]$} \\
\hline Czechy & $-2,79$ & {$[8,437]$} & $-7,32$ & {$[9,07]$} & & \\
\hline Dania & 8,47 & {$[7,153]$} & & & 2,56 & {$[2,412]$} \\
\hline Estonia & $-10,11$ & {$[7,309]$} & $-13,81$ & {$[8,13]^{*}$} & & \\
\hline Finlandia & $-4,12$ & {$[7,238]$} & & & $-11,52$ & {$[2,441]^{\star * *}$} \\
\hline Francja & $-7,93$ & {$[7,283]$} & & & $-14,40$ & {$[2,825]^{\star * *}$} \\
\hline Gruzja & $-9,52$ & {$[7,21]$} & & & & \\
\hline Niemcy & 4,74 & {$[7,188]$} & & & $-2,00$ & {$[2,501]$} \\
\hline Grecja & $-3,02$ & {$[7,404]$} & & & & \\
\hline Węgry & $-8,84$ & {$[7,305]$} & $-13,07$ & {$[7,994]$} & & \\
\hline Islandia & 10,95 & {$[7,138]$} & & & 4,69 & {$[2,22]^{\star *}$} \\
\hline Irlandia & $-6,63$ & {$[7,15]$} & & & $-12,27$ & {$[2,491]^{* * *}$} \\
\hline Izrael & 1,79 & {$[7,26]$} & & & & \\
\hline Włochy & 6,87 & {$[7,207]$} & & & $-0,26$ & {$[1,902]$} \\
\hline
\end{tabular}




\begin{tabular}{|c|c|c|c|c|c|c|}
\hline \multirow{2}{*}{\begin{tabular}{|c|c|}
$\begin{array}{c}\text { Zmienna } \\
\text { objaśniająca }\end{array}$ \\
Japonia
\end{tabular}} & \multicolumn{2}{|c|}{ Wszystkie kraje (7) } & \multicolumn{2}{|c|}{ Europa Wschodnia (8) } & \multicolumn{2}{|c|}{ Europa Zachodnia (9) } \\
\hline & $-10,09$ & {$[7,158]$} & & & & \\
\hline Łotwa & 0,35 & {$[7,416]$} & $-3,76$ & {$[7,691]$} & & \\
\hline Litwa & $-17,03$ & {$[8,001]$} & $-20,43$ & {$[8,51]^{* *}$} & & \\
\hline Luksemburg & 7,48 & {$[7,442]$} & & & & \\
\hline Macedonia & $-10,78$ & {$[8,28]$} & $-12,24$ & {$[9,984]$} & & \\
\hline Malta & 22,25 & {$[7,245]^{* * *}$} & & & 14,90 & {$[2,327]^{* * *}$} \\
\hline Meksyk & $-22,54$ & {$[7,425]^{* * *}$} & & & & \\
\hline Mołdawia & $-5,80$ & {$[7,435]$} & $-10,14$ & {$[8,13]$} & & \\
\hline Holandia & 4,23 & {$[7,194]$} & & & $-3,14$ & {$[2,294]$} \\
\hline Nowa Zelandia & 7,26 & {$[7,198]$} & & & & \\
\hline Norwegia & 1,97 & {$[7,171]$} & & & $-3,74$ & {$[2,374]$} \\
\hline Polska & $-25,45$ & {$[7,538]^{* * *}$} & $-28,93$ & {$[8,269]^{* * *}$} & & \\
\hline Portugalia & $-4,45$ & {$[7,394]$} & & & $-10,62$ & {$[3,256]^{* * *}$} \\
\hline Rumunia & $-14,36$ & {$[9,345]$} & $-18,61$ & {$[9,886]^{*}$} & & \\
\hline Rosja & $-15,65$ & {$[8,022]^{*}$} & & & & \\
\hline Serbia & $-11,69$ & {$[7,219]$} & $-14,76$ & {$[7,88]^{*}$} & & \\
\hline Słowacja & $-0,69$ & {$[8,632]$} & $-4,60$ & {$[8,873]$} & & \\
\hline Słowenia & $-3,62$ & {$[7,801]$} & $-7,61$ & {$[8,534]$} & & \\
\hline RPA & 9,00 & {$[7,757]$} & & & & \\
\hline Korea Południowa & $-13,86$ & {$[7,971]^{\star}$} & & & & \\
\hline Hiszpania & $-2,16$ & {$[7,296]$} & & & $-8,31$ & {$[2,895]^{\star * *}$} \\
\hline Szwecja & 8,52 & {$[7,102]$} & & & 3,69 & {$[2,479]$} \\
\hline Szwajcaria & $-27,83$ & {$[7,28]^{\star * *}$} & & & $-35,13$ & {$[2,706]^{* * *}$} \\
\hline Turcja & $-0,11$ & {$[8,13]$} & & & & \\
\hline Ukraina & $-5,06$ & {$[7,192]$} & $-9,03$ & {$[7,961]$} & & \\
\hline Wielka Brytania & $-6,77$ & {$[7,245]$} & & & $-13,54$ & {$[2,657]^{* * *}$} \\
\hline $\begin{array}{l}\text { Stany } \\
\text { Zjednoczone }\end{array}$ & $-4,06$ & {$[7,271]$} & & & & \\
\hline L. obserwacji & 517 & & 129 & & 246 & \\
\hline L. parametrów & 58 & & 23 & & 25 & \\
\hline $\mathrm{R} 2$ & $83,0 \%$ & & $61,2 \%$ & & $88,8 \%$ & \\
\hline Adj. R2 & $80,9 \%$ & & $53,2 \%$ & & $87,6 \%$ & \\
\hline test F & $39,3^{\star * *}$ & & $7,609^{* * *}$ & & $72,95^{\star * *}$ & \\
\hline
\end{tabular}




\begin{tabular}{|l|c|l|c|l|c|l|}
\hline $\begin{array}{c}\text { Zmienna } \\
\text { objaśniająca }\end{array}$ & \multicolumn{2}{|c|}{ Wszystkie kraje (7) } & \multicolumn{2}{c|}{ Europa Wschodnia (8) } & \multicolumn{2}{c|}{ Europa Zachodnia (9) } \\
\hline Norm test Chi ^2 & $60,77^{* * *}$ & & 1,152 & & 3,0479 & \\
\hline Hetero test (F) & $4,5277^{* * *}$ & & $2,2514^{\star * *}$ & & $4,7879^{* * *}$ & \\
\hline RESET23 (F) & $23,742^{* * *}$ & & $3,4284^{* *}$ & & $20,187^{* * *}$ & \\
\hline
\end{tabular}

Oszacowania parametrów modeli regresji liniowej metodą najmniejszych kwadratów (OLS); Błędy standardowe HCSE; Zmienna objaśniana: frekwencja; Błędy oszacowania znajdują się w nawiasach kwadratowych.

${ }^{\star} \mathrm{p}<0,05 ;{ }^{* *} \mathrm{p}<0,01 ;{ }^{* *} \mathrm{p}<0,001$.

Wszystkie modele charakteryzują się wysokim poziomem skorygowanego współczynnika determinacji R2, co świadczy o dobrej jakości dopasowania modeli. W przypadku modeli (1)-(6) współczynnika R2 mieści się w przedziale od $33 \%$ do $39 \%$, a w przypadku modeli (7)-(9) w przedziale od $53 \%$ do $88 \%$.

We wszystkich modelach wartość statystyki F prowadzi do odrzucenia na poziomie istotności $1 \%$ hipotezy zerowej o braku łącznej istotności wszystkich parametrów modelu, co oznacza, że zmienne objaśniające mają statystyczny wpływ na zmienną objaśnianą.

W modelach (1), (2), (5),(6), (7), na poziomie istotności 1\% można odrzucić hipotezę o normalności składników losowych. W przypadku wszystkich modeli można odrzucić hipotezę o homoskedastyczności składnika losowego, co nie stanowi problemu, ponieważ we wszystkich modelach oszacowane zostały błędy standardowe odporne na heteroskedastyczność (HSCE). W przypadku modeli (1), (2), (3), (4), (7), (8), (9) można odrzucić hipotezę o liniowej specyfikacji modelu (na poziomie 1\% lub 5\%). Ze względu na dużą liczebę prób w modelach, brak normalności składników resztowych oraz brak liniowej specyfikacji modeli zostały zignorowane.

\section{Wyniki}

1. W modelach (1), (2) na poziomie istotności $1 \%$ brak podstaw do odrzucenia hipotezy o istotności współczynników przy zmiennych binarnych dotyczących systemu wyborczego. Oznacza to, że w skali globalnej system wyborczy ma wpływ na frekwencję wyborczą. We wszystkich modelach pominiętą zmienną binarną jest proporcjonalny system list wyborczych, do którego można odnieść wartości współczynników przy zmiennych 
dotyczących systemu wyborczego. Można zauważyć w skali globalnej, że systemy większościowe oraz mieszane charakteryzują się niższą frekwencją niż systemy proporcjonalne. Wyjątkiem jest australijski alternatywny system większościowy, w którym frekwencja jest wyższa niż w proporcjonalnych systemach wyborczych.

2. W modelach (5) i (6) na poziomie istotności $1 \%$ brak podstaw do odrzucenia hipotezy o istotności współczynników przy zmiennych binarnych dotyczące systemu wyborczego. Oznacza to, że w przypadku krajów Europy Zachodniej system wyborczy ma wpływ na frekwencję wyborczą. W Europie Zachodniej systemy większościowe charakteryzują się niższą frekwencją niż systemy proporcjonalne, natomiast systemy mieszane charakteryzują się wyższą frekwencją niż systemy proporcjonalne.

3. W modelach (3) i (4) współczynniki przy zmiennych dotyczących systemu wyborczego nie są statystycznie istotne, co oznacza że w przypadku Europy Wschodniej system wyborczy nie ma wpływu na frekwencję.

4. Jedynie w modelu (2) na poziomie istotności $1 \%$ brak podstaw do odrzucenia hipotezy o istotności współczynnika przy zmiennej polaryzacja. W pozostałych modelach można odrzucić hipotezę o istotności tego współczynnika. Ponieważ w modelach (7), (8) i (9) przeprowadzone zostały mocniejsze testy postawionej hipotezy, autor wnioskuje, że polaryzacja sceny politycznej nie ma statystycznego wpływu na frekwencje wyborczą.

\section{DYSKUSJA}

Analiza związku pomiędzy systemem wyborczym, polaryzacją oraz poziomem frekwencji wyborczej jest bogatym nurtem teorii wyboru publicznego. Przeprowadzone badanie wykazało, że system wyborczy wpływa na poziom frekwencji zarówno na poziomie globalnym, jak i w krajach Europy Zachodniej. W obu przypadkach ordynacje większościowe charakteryzują się niższą frekwencją niż systemy proporcjonalne, z kolei mieszane systemy wyborcze charakteryzują się niższą frekwencją niż systemy proporcjonalne w skali światowej, natomiast wyższą frekwencją w krajach Europy Zachodniej. Australijski alternatywny system większościowy stanowi wyjątek od powyższej zasady, ponieważ cechuje się wyższą frekwencją niż proporcjonalne systemy wyborcze. Przyczynowy związek pomiędzy ordynacją wyborczą a frekwencją nie istnieje w krajach 
Europy Wschodniej, w której funkcjonują jedynie proporcjonalne oraz mieszane ordynacje wyborcze.

Badanie nie wykazało wpływu polaryzacji sceny politycznej na wielkość frekwencji wyborczej. Może to wynikać $\mathrm{z}$ istnienia wielu kanałów wzajemnego wpływu polaryzacji oraz frekwencji oraz ich sprzężenia zwrotnego zgodnie z obrazem przedstawionym w części teoretycznej artykułu.

\section{BiBLIOGRAFIA:}

Arnold, F., Freier, R. (2015). The Partisan effects of voter turnout. How conservatives profit from rainy election days. Discussion Papers. Berlin: Deutsches Institut für Wirtschaftsforschung 1463.

Barone, G., De Blasio, G. (2013). Electoral rules and voter turnout. International Review of Law and Economics, 36, 25-35.

Black, D. (1948). On the rationale of group decision making. Journal of Political Economy, 56(1), 23-34.

Dalton, R.J. (2008). The quantity and the quality of party systems. Party system polarization, its measurement, and its consequences. Comparative Political Studies, 41 (7), 899-920.

Dassonneville, R., Hooghe, M. (w druku). Economic indicators and electoral volatility. Economic effects on electoral volatility in Western Europe, 1950-2013. Comparative European Politics.

Downs, A. (1957). An Economic theory of political action in a democracy. Journal of Political Economy, 65 (2), 135-150.

Fiorina, M.P. (1999). Whatever happened to the median voter? Prepared for the MIT Conference on Parties and Congress, Cambridge.

Fumagalli, E., Narciso, G. (2012). Political institutions, voter turnout and policy outcomes. European Journal of Political Economy, 28 (2), 162-173.

Geys, B. (2006a). Explaining voter turnout. A review of aggregate-level research. Electoral Studies, 25, 637-663.

Gays, B. (2006b). Rational theories of voter turnout. Political Studies Review, 4, 16-35.

Hansford, T.G., Gomez B.T. (2010). Estimating the electoral effects of voter turnout. American Political Science Review, 104 (2), 268-288.

Hetherington, M.J. (2008). Turned off or turned on: The effects of polarization on political participation, engagement and representation. W: D. Brady, P. Nivola, Red and blue nation? Vol 2. Washington DC: Brookings.

Ladner, A., Milner, H. (1999). Do voters turn out more under proportional than majoritarian systems? The evidence from Swiss communal elections. Electoral Studies, $18,235-250$.

Mata Lopez, T. (2013). The factors of the voting equation: An empirical analysis. Revista Española de Investigaciones Sociológicas, 143, 47-74. 
Matakos, K., Troumpounis, O., Xefteris, D. (2015). Turnout and polarization under alternative electoral systems. W: N. Schofield, G. Caballero. (red.), The political economy of governance. Institutions, political performance and elections (s. 335-362). Springer International Publishing. DOI: 10.1007/978-3-319-15551-7_18.

Mueller, D.C. (red.). (2003). Public choice III. New York: Cambridge University Press.

Murphy, T. (2009). Why do people vote? Examining the determinants of electoral participation in the world's democracies. Lexington Senior Seminar, Transylvania University.

Myatt, D.P. (2012). A rational choice theory of voter turnout. London Business School.

Ortoleva P., Snowberg, E. (2013). Overconfidence in political behavior. Working Paper No. 19250, NBER.

Riker, H., Ordeshook, P. (1968). A theory of the calculus of voting. American Political Science Review, 62(1), 25-42.

Rogowski, J. (2015). Increased polarization in politics reduces voter turnout. Pobrane z: http://blogs.lse.ac.uk/usappblog/2013/12/04/increased-polarization-in-politicsreduces-voter-turnout.

Sanz, C. (w druku). The effect of electoral systems on voter turnout: Evidence from a natural experiment. Political Science Research and Methods.

Steenkiste, P. (2015). The effect of voter turnout on political polarization. Pobrane z: http://cacs.org/research/effect-voter-turnout-political-polarization/.

Valasek, J. (2012). Get out the vote: How encouraging voting changes political outcomes. Economics \& Politics, 24 (3), 346-373.

Volkens, A., Lehmann, P., Matthieß, T., Merz, N., Regel, S., Werner, A. (2015). The Manifesto Data Collection. Manifesto Project (MRG/CMP/MARPOR). Version 2015 a. Berlin: Wissenschaftszentrum Berlin für Sozialforschung (WZB).

Wilkin, J. (2005). Teoria wyboru publicznego. Wstęp do analizy polityki i funkcjonowania sfery publicznej. Warszawa: Wydawnictwo Naukowe Scholar. 